\title{
1. Introduction: contracting human rights
}

\section{Alison Brysk}

Human rights at 70 is both expanding and contracting. On the one hand, the human rights regime is expanding through introducing new actors, claims, mechanisms, and proposed responsibilities (Brysk and Stohl 2017). These expansions may contest dehumanization, introduce new frames, foster rights interdependence, build new transnational networks and processes, construct global governance beyond law and state-based institutions, and transform practice through disseminating new norms, models, and benchmarks. Yet our survey of that expansion concluded that responsibilities to protect remain tragically inadequate to current conditions, new problems continue to arise that transcend the current system, new actors seeking to transform the system may instead be suppressed, and promising new human rights claims too often encounter resistance and counter-mobilization.

In this volume, we assess the historic status of these contractions, in the global context of worldwide increases in economic inequality and security threats that have added new costs to chronic gaps that affect the legitimacy and leverage of the international human rights regime. Are contemporary shortfalls in the rights regime the reflection of continuities or a reemergence of long-standing trends? Or do they represent a regression from the hard-won gains of generations of global governance, in response to fundamental shifts in underlying conditions or understandings?

We find that the current contraction of human rights reflects a reconfiguration of global governance in a post-cosmopolitan era, marked by a simultaneous resilience of sovereignty in some domains contrasting with a relocation of authority above and below the state in other areas. Just as international relations theorist Susan Strange concluded at the dawn of the era of globalization that the state is at the same time "widening, wavering, and withering," a generation later states and publics meet the expanding demands of the human rights regime with an uneasy blend of compliance, resistance, evasion, and undermining. We know from a generation of human rights research that the general drivers of rights reform include 
norm change, social mobilization, institutionalization, state capacity, coalition-building and shifting interests of authorities (Risse et al. 2013). Our task will be to map some of the determinants and parameters of rights regression: from citizenship gaps to declining state capacity, legal zones of permanent exception, disempowerment of challengers, and contradictions between national and global citizenship.

\section{MAPPING CONTRACTIONS}

Human rights are contracting in the sense of growing smaller, but also in the sense of becoming more contractual. Rights are often impeded by various shortfalls in the social contract at all levels: citizenship gaps that block the standing of new actors, accountability gaps that undermine the potential of new mechanisms, and increasingly legalized backlash by sovereign states who thrive on the breakdown of solidarity. Increasingly, it appears that the key variable in the gap between commitment and compliance is an emerging contraction of accountability for some domains of authority, alongside the long-standing dilemmas of contracting accountability for the full range of national, international, and transnational actors. At the same time, we propose that the most innovative and helpful strategies for human rights promotion and expansion will be precisely those that address these contractions.

We will focus on these global and local challenges to human rights in the areas of gaps, backlash, accountability - and new opportunities that point the way forward. We examine these problems in a global perspective, including rights problems in Europe, the Middle East, Latin America, and the U.S. We will analyze trends across multiple issue-areas of international institutions, development struggles, humanitarian action, censorship and communications, discrimination, democracy promotion, human trafficking, counter-terrorism, corporate social responsibility, and civil society and social movements. Our contributors represent a wide range of international scholarship from the U.S., Mexico, Spain, Austria, the UK, and Denmark, with backgrounds in law, political science, sociology, history, and communications.

First, we review the widening citizenship gaps in human rights coverage for refugees, socioeconomic rights, women's rights in patriarchal societies, and civil liberties in chronic conflict, first outlined in Brysk and Shafir (2004). These are cases where the rights regime is incomplete or permits unsustainable exception, and current security and development crises are intensifying these contradictions. For several of these issues-refugees, Latin American states of emergency, and Israeli occupation-there is a 
systematic contradiction between popular democracy and international rights norms.

Alison Brysk begins with the long-standing gap between universal rights and sovereign citizenship enforcement noted by Hannah Arendt, tragically illustrated generations later by the 21 st century refugee crisis (Arendt 1958). In a different register, Gershon Shafir documents how Israel's securitization of citizenship inspired by the occupation's unsustainable exceptionalism to international law blows back to undermine civil liberties even of the dominant population. For Claire Wright, the gaps built into the international regime are exceptionalist legacies of states of emergency in Latin America, now abused by democratic governments to subvert popular participation in decision-making over natural resource extraction. In another illustration of how unequal development undermines rights in developing democracies, Natasha Bennett shows how lack of state capacity and political will leaves slum areas ungoverned and states unaccountable for contracting social and economic rights such as housing.

Then, we move to consider a new layer of unexpected problems for rights promotion following a generation of expansion: backlash. In these cases, the successful development of new rights norms and policies triggers counter-mobilization and state suppression. States may ban, attack, or condition international and local human rights monitors and defenders and the international regime offers little recourse against violence, censorship, harassment, or defunding. Beyond behavioral non-compliance, both states and local civil societies may regress and reject hard-won international norms even on first-generation war crimes and anti-discrimination, especially in areas of high perceived threat, such as national insecurity and struggles over sexuality and gender identity.

Clair Apodaca shows how well-intentioned universalist campaigns by NGOs may founder on state retribution against local partners, while Philip M. Ayoub depicts a parallel state manipulation of nationalist and religious counter-norms to discredit transnational campaigns for LGBT rights in the new Europe. At the interstate level, Felipe Gómez Isa analyzes Egypt's resistance to EU democracy and human rights initiatives, as a dependent authoritarian state that still has the power to evade leverage by one of the strongest regional promotion regimes. Finally, deep in the heart of the state, Arturo Jimenez-Bacardi documents the rise and fall of legalized bureaucratic politics as a mechanism for human rights accountability in U.S. foreign policy on torture and targeted assassination.

We go on to examine how, in the face of these continuing and emerging challenges, the international regime's legal mechanisms of accountability often struggle for traction (Brysk 2013). In the second and third generation of legalization, George Andreopoulos and Wayne Sandholtz et al. show 
how global governance institutions like the UN Security Council and regional courts often still fail to overcome the constraints of state sovereignty to uphold rights. As Kirsten Ainley discusses, resistant states may even come to contest the foundations of universalism, as in withdrawal from the International Criminal Court. Meanwhile, accountability for non-state perpetrators of labor abuse expand in theory but contract in practice in the absence of compulsory enforcement, as seen in the chapter by Julia Planitzer et al. Even as regional regimes and civil litigation advance potential mechanisms of accountability for "private wrongs" (Brysk 2005), the private sector actors at the table or in the courtroom are less relevant for the harms of trafficking and exploitation than lower-level perpetrators in weakly governed zones.

However, despite these growing gaps, the globalization of human rights continues to present new opportunities as well as challenges (Brysk 2002). Our analysis suggests increased attention to expanding mobilizations, norms, and mechanisms that address the patterns identified above. Thus, we consider new grassroots mechanisms to address the accountability gap in corporate social responsibility (Vestergaard and Etter), new uses of communication to deepen citizen participation and inclusion for recognition of sexual minorities (Stohl et al.), and new movements and transnational coalitions that bridge rival norms and identities of feminism and Islam (Faust). Moreover, Feryal M. Cherif demonstrates the forward linkages and positive interdependence of promotion of women's social and economic rights to increase women's legal rights, ameliorating one of the most widespread and chronic global inequities.

\section{CONCLUSION}

Taken together, these chapters suggest we may need to rethink some of the assumptions of a generation of human rights scholarship concerning the evolution of norms, the nature of law, and the relationship between the national and global order. Why do new rights norms and claims inspire backlash despite diffusion of rights talk and changes in world culture? When does legalization unwittingly undermine rights or permit evasion rather than compliance? As we move from the state as target of protest to intermittent enforcer of rights, how can we cope with contradictions between the state's multiple interests in maximizing its own authority, supporting world order, and reflecting citizen preferences - which in each case may be liberal or nationalist?

Beyond academic analysis to policy and practice, Contracting Human Rights aims to contribute to building understanding of the 21st century 
maturation of human rights, from a dissident doctrine to a dynamic parameter of global governance and civil society. We chronicle the continuing contest over the reach, range, and regime of rights in order to analyze the way forward, in an era of great challenge. In that process, we will see that even though some dimensions of rights are now unexpectedly contracting, the contract for the next generation of rights is still being written - and that we are all potential participants in rewriting rights with the knowledge we gain.

\section{REFERENCES}

Arendt, Hannah. The Human Condition. University of Chicago Press, 1958.

Brysk, Alison (ed.). Globalization and Human Rights. Berkeley, CA: University of California Press, 2002.

Brysk, Alison. Human Rights and Private Wrongs. Routledge Press, 2005.

Brysk, Alison (ed.). The Politics of the Globalization of Law. Routledge Press, 2013.

Brysk, Alison and Gershon Shafir (eds). People Out of Place: Globalization and the Citizenship Gap. Routledge Press, 2004.

Brysk, Alison and Michael Stohl (eds). Expanding Rights: 21st Century Norms and Governance. Edward Elgar, 2017.

Risse, Thomas, Stephen Ropp, and Kathryn Sikkink (eds). The Persistent Power of Human Rights. Cambridge University Press, 2013. 
Alison Brysk - 9781788112338

Downloaded from PubFactory at $04 / 26 / 2023$ 11:12:24AM via free access 